\title{
Cytotoxic edema: mechanisms of pathological cell swelling
}

\author{
Danny Liang, M.D., ${ }^{1}$ Sergei Bhatta, M.S. ${ }^{1,3}$ Volodymyr Gerzanich, M.D., Ph.D., ${ }^{1}$ AND \\ J. Marc Simard, M.D., Ph.D. ${ }^{1,2,3}$ \\ Departments of ${ }^{1}$ Neurosurgery, ${ }^{2}$ Pathology, and ${ }^{3}$ Physiology, University of Maryland School \\ of Medicine, Baltimore, Maryland
}

\begin{abstract}
$\checkmark$ Cerebral edema is caused by a variety of pathological conditions that affect the brain. It is associated with two separate pathophysiological processes with distinct molecular and physiological antecedents: those related to cytotoxic (cellular) edema of neurons and astrocytes, and those related to transcapillary flux of $\mathrm{Na}^{+}$and other ions, water, and serum macromolecules. In this review, the authors focus exclusively on the first of these two processes. Cytotoxic edema results from unchecked or uncompensated influx of cations, mainly $\mathrm{Na}^{+}$, through cation channels. The authors review the different cation channels that have been implicated in the formation of cytotoxic edema of astrocytes and neurons in different pathological states. A better understanding of these molecular mechanisms holds the promise of improved treatments of cerebral edema and of the secondary injury produced by this pathological process.
\end{abstract}

KeY Words - cation channel - cytotoxic edema - hypoxia • stroke • sulfonylurea receptor 1 - traumatic brain injury

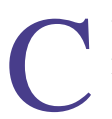

YTOTOXIC EDEMA IN THE CNS is typically accompanied by brain swelling. Edema can result from almost any insult to the brain, including trauma, infarction, neoplasm, abscess, or conditions such as hypoxia or toxic or metabolic perturbation. ${ }^{10,93,94}$ Stroke and traumatic brain injury are especially prevalent causes of morbidity and mortality. In the US, stroke is the third most common cause of death, with more than 730,000 firsttime incidents each year. ${ }^{47,126}$ Traumatic brain injury afflicts 1.4 million people yearly, resulting in 50,000 deaths and 235,000 hospitalizations..$^{82,83,131,151}$

Cytotoxic edema is defined as the premorbid cellular process, otherwise known as cellular edema, oncotic cell swelling, or oncosis, whereby extracellular $\mathrm{Na}^{+}$and other cations enter into neurons and astrocytes and accumulate intracellularly, in part due to failure of energy-dependent mechanisms of extrusion. Unchecked influx of cations occurs largely through cation channels. Cation influx, in turn, drives influx of anions, which maintains electrical neutrality, and in combination these phenomena drive influx of water, resulting in osmotic expansion of the cell,

Abbreviations used in this paper: ADP = adenosine diphosphate; $\mathrm{AQP}=$ aquaporin; $\mathrm{ASIC}=$ acid-sensing ion channel; $\mathrm{ATP}=$ adenosine triphosphate; $\mathrm{CNS}=$ central nervous system; $\mathrm{CSF}=$ cerebrospinal fluid; $\mathrm{MCA}=$ middle cerebral artery; $\mathrm{NC}_{\mathrm{Ca}-\mathrm{ATP}}=$ calciumactivated, ATP-sensitive nonselective cation; $\mathrm{NKCC}=\mathrm{Na}^{+} / \mathrm{K}^{+} / 2 \mathrm{Cl}^{-}$ cotransporter; NMDA $=N$-methyl-D-aspartate; SUR1 = sulfonylurea receptor 1 ; TRP $=$ transient receptor potential; TRPC $=$ TRP canonical; TRPM = TRP melastatin; TRPV = TRP vanilloid. that is, cytotoxic edema. Cytotoxic edema by itself does not result in brain swelling, but formation of cytotoxic edema depletes the extracellular space of $\mathrm{Na}^{+}, \mathrm{Cl}^{-}$, and water, thereby creating a new gradient for these molecules across the capillary of the blood-brain barrier. With appropriate changes in capillary permeability, ${ }^{138}$ the new gradient created by cytotoxic edema results in driving transcapillary formation of ionic edema. Thus, cytotoxic edema is important in its own right, because it signals a premorbid cellular process that almost inevitably leads to oncotic or necrotic cell death. But equally important, cytotoxic edema supplies the driving force for the formation of ionic edema, which is the process that introduces new mass $\left(\mathrm{Na}^{+}, \mathrm{Cl}^{-}, \mathrm{H}_{2} \mathrm{O}\right)$ that is ultimately responsible for brain swelling. ${ }^{138}$

Excellent reviews that summarize current knowledge on this topic have been published. ${ }^{20,21,37,46,71-73,112,125,166}$ In our recent review, ${ }^{138}$ we examined molecular mechanisms involved in transcapillary flux of $\mathrm{Na}^{+}$, water, plasma ultrafiltrate, and blood that lead to brain swelling. In this paper, we review molecular mechanisms involved in cytotoxic edema.

\section{Pathophysiology of Cytotoxic Edema}

When an insult to the brain results in ischemia or hypoxia, very little new ATP can be produced due to abrogation of oxidative phosphorylation. ${ }^{56}$ Cells quickly use up their reserves of ATP and, unless normoxia is restored, the deranged cellular machinery loses its ability to sustain 
homeostasis. Primary active transport, mainly ATP-dependent $\mathrm{Na}^{+} / \mathrm{K}^{+}$ATPase that requires continuous expenditure of ATP, is necessary to maintain homeostais. ${ }^{146,162}$ The balance between survival and death is determined by the struggle between electrogenic pump activity and channels that enable $\mathrm{Na}^{+}$to enter into cells. ${ }^{137,161}$ Cellular survival requires that $\mathrm{Na}^{+}$be continuously extruded from the intracellular compartment, because this is critical to maintaining normal cell volume.

Depletion of ATP is accompanied by unchecked influx of extracellular ions, primarily $\mathrm{Na}^{+}$, down their electrochemical gradients. This influx is driven by energy stored in preexisting ionic gradients across the cell membrane. ${ }^{84}$ Sodium ion influx in turn drives $\mathrm{Cl}^{-}$influx via chloride channels, and the resultant increase in intracellular osmolarity drives inflow of water via AQP channels (among others), ${ }^{8,11,12,46,71-73,75}$ Extracellular water flows into the cell interior, resulting in an increase in intracellular fluid volume, at the expense of the extracellular space. Morphologically, this process results in alterations in membrane surface architecture with prominent bleb formation. In the initial stages of cytotoxic edema, the blood-brain barrier is intact and largely impermeable to ions and fluids, so extracellular ions and water loss are not replenished. Thus, fluid movement involved in formation of cytotoxic edema does not lead to any change in total brain volume, despite the observable increase in cell size.

Cells in both gray and white matter are affected by cytotoxic edema. ${ }^{52}$ Cellular swelling begins within 30 minutes of MCA occlusion, particularly around capillaries, persists for up to 24 hours after reperfusion, ${ }^{43,44}$ and results in an average reduction of extracellular space from the normal $20 \%$ down to 4 to $10 \% .{ }^{86,147}$ Astrocytic swelling is much more prominent than neuronal swelling. Astrocytes are more prone to pathological swelling than neurons, because they are involved in clearance of $\mathrm{K}^{+}$and glutamate, which cause osmotic overload that in turn promotes water inflow. Astrocytic but not neuronal NKCC is upregulated by elevated extracellular $\mathrm{K}^{+}$and cell swelling. ${ }^{100,142,143}$ Expression of high levels of the water channel AQP4 is also important. ${ }^{90,91}$

When compensatory mechanisms such as ionic pumps in the plasma membrane are exceeded or fail altogether, the swollen cell dies. ${ }^{148}$ This pathway to cell death was called oncosis (derived from the Greek word "onkos," which means swelling) by von Recklinghausen, specifically to describe cell death by swelling. This term is a more specific way of classifying cellular demise than the less precise terms "accidental cell death" or "necrosis." Oncotic cell death also differs in important ways from apoptotic cell death. At the electron-microscopic level, the difference between the two pathways leading to cell death becomes apparent: oncosis leads to cells that show a noticeable increase in volume and presents with membrane damage to plasmalemma and other organelle membranes, along with loss of membrane phospholipids and disappearance of stainable nuclei at the late stage; ${ }^{14,15}$ in contrast, apoptosis presents with cell involution and shrinkage ${ }^{89,111}$ before death ensues.

\section{Cation Channels Involved in Cytotoxic Edema}

Experimental evidence shows a clearly delineated se- quence of metabolic responses of brain tissue to a decrease in blood flow. ${ }^{60-62,66,69}$ The brain area where blood flow is either absent or measures less than $10 \mathrm{ml} / 100 \mathrm{~g}$ (brain tissue)/min is rapidly and irreversibly damaged in less than 6 minutes, forming an "ischemic core." This infarcted tissue is surrounded by the "penumbra" of hypoxic but living tissue with blood flow greater than $20 \mathrm{ml} / 100 \mathrm{~g}$ (brain tissue)/min. Cells in the penumbra undergo cytotoxic edema and other changes that are potentially reversible if perfusion is restored within the first few hours after injury. If hypoxic conditions persist, however, penumbral cells with cytotoxic edema eventually die, extending the course of cell death deeper into the parenchyma than the originally involved core. The penumbra, therefore, is the main therapeutic target in the prevention of ischemic stroke and injury.

A number of studies have now shown that pharmacological inhibition of ion channels, including nonselective cation channels, reduces focal ischemic injury in rodent models of ischemic stroke. ${ }^{59,98,118,172}$ Nonselective cation channels are distinguished from selective cation channels by their permeability properties; ion selective channels are typically permeable to a single cation, such as $\mathrm{Na}^{+}, \mathrm{K}^{+}$, or $\mathrm{Ca}^{2+}$, whereas a nonselective cation channel may allow flux of any monovalent cation, or even a mixture of monovalent and divalent cations. It is likely that these channels play an important role in secondary injury in the penumbra, ${ }^{139}$ and thus targeting these channels offers the possibility of reducing secondary injury. In the sections that follow, we review several of the nonselective cation channels that have been implicated in cytotoxic edema and secondary injury in the penumbra.

\section{The ASIC Channel}

Acid-sensing ion channels are members of the recently discovered epithelial sodium channel/degenerin gene family of ion channels. Acid-sensing ion channel genes encode proton-gated cation channels in both the central and peripheral nervous system. ${ }^{153,154}$ Six different ASIC subunits have been cloned to date, which are encoded by four genes, ASICI-ASIC4. ${ }^{16}$

Acid-sensing ion channels are hydrogen ion-gated cation channels that are activated as $\mathrm{pH}$ falls but are generally inactive at physiological $\mathrm{pH}$ (7.4). All ASICs are permeable to $\mathrm{Na}^{+}$and, to a lesser degree, to $\mathrm{Ca}^{2+}$ and are blocked by amiloride. Activation of these channels leads to an increase in cell excitability.

First noted in sensory neurons, ${ }^{77-79}$ and later implicated in acid-induced nociception in mammals, ${ }^{152}$ ASICs have most recently been shown to be involved in the detection of ischemic pain. ${ }^{105,170}$ The ASIC subunits ASIC1a and ASIC2a have attracted scientific attention in the context of neuroprotection. Ischemia and hypoxia result in a marked reduction in tissue $\mathrm{pH}$ due to uncontrolled generation of lactic acid, and acidosis is an important determinant of neurological injury. ${ }^{106,124}$ The ASIC1a subunit may be responsible for acidosis-mediated, glutamate receptorindependent neuronal injury. ${ }^{167,168}$ The probability of opening of ASIC1a increases as the $\mathrm{pH}$ decreases below 7.0, and activation is half of maximum at a $\mathrm{pH}$ of 6.2 , which is in the range of $\mathrm{pH}$ that is thought to occur within the penumbra and core of an infarct, especially in the context 
of hyperglycemia. ${ }^{106}$ Activation of ASIC1a is promoted by stretching of the membrane, release of arachidonic acid, production of lactate, ${ }^{6,64}$ or a drop in extracellular $\mathrm{Ca}^{2+}$ concentration, ${ }^{65}$ conditions that occur within an infarct as cells swell, $\mathrm{Ca}^{2+}$-dependent phospholipases are activated, and $\mathrm{Ca}^{2+}$ influx occurs. ${ }^{19}$

Activation of ASIC1a in vitro results in an increase in intracellular $\mathrm{Ca}^{2+}$ and induces time-dependent neuronal injury that occurs in the presence of the blockers of voltagegated $\mathrm{Ca}^{2+}$ channels and glutamate receptors. In rodent in vivo models of ischemic stroke, intracerebroventricular administration of the ASIC1a blockers amiloride and tarantula toxin (psalmotoxin 1) prior to onset of ischemia, as well as knockout of the ASICla gene, reportedly prevents ischemic injury. ${ }^{168}$

The channel ASIC2a has garnered particular interest because transient global ischemia induces its expression in the rat brain, including in neurons of the hippocampus and cortex. $^{68}$

\section{The SURI-Regulated $N C_{\text {Ca-ATP }}$ Channel}

The $\mathrm{NC}_{\mathrm{Ca}-\mathrm{ATP}}$ channel is a novel cation channel that conducts all inorganic monovalent cations, but is impermeable to $\mathrm{Ca}^{2+}$ and $\mathrm{Mg}^{2+} \cdot{ }^{26}$ Opening of this channel requires nanomolar $\mathrm{Ca}^{2+}$ on the cytoplasmic side. Physiological levels of ATP intracellularly block $\mathrm{NC}_{\mathrm{Ca}-\mathrm{ATP}}$ channel opening, whereas depletion of ATP triggers channel opening.

The $\mathrm{NC}_{\mathrm{Ca}-\mathrm{ATP}}$ channel is believed to be composed of poreforming and regulatory subunits. The regulatory subunit is SUR1, the same as that for $K_{\text {ATP }}$ channels in pancreatic $\beta$ cells. ${ }^{25}$ Knockdown of SUR1 using antisense oligodeoxynucleotide reduces SUR1 expression ${ }^{137}$ and prevents expression of functional $\mathrm{NC}_{\mathrm{Ca}-\mathrm{ATP}}$ channels (Simard and Chen, unpublished data). Because SUR1 is involved in channel regulation, pharmacological agents that affect the SUR1regulated $\mathrm{K}_{\text {ATP }}$ channel also affect the $\mathrm{NC}_{\text {Ca-ATP }}$ channel. Thus, $\mathrm{NC}_{\mathrm{Ca}-\mathrm{ATP}}$ channel opening is blocked by sulfonylurea compounds such as tolbutamide and glibenclamide, and channel activity is increased by diazoxide.

The $\mathrm{NC}_{\mathrm{Ca}-\mathrm{ATP}}$ channel is not constitutively expressed, but is expressed in the CNS following hypoxia or injury. The channel was first discovered in freshly isolated reactive astrocytes obtained from the hypoxic inner zone of the gliotic capsule. ${ }^{25,26}$ Since then, it has also been identified in neurons from the core of an ischemic stroke. ${ }^{137}$ In rat models of ischemic stroke, the SUR1 regulatory subunit is transcriptionally upregulated in neurons, astrocytes, and capillary endothelial cells.

The consequences of channel opening have been studied in isolated cells that express the channel, by depleting ATP using $\mathrm{Na}^{+}$azide or $\mathrm{Na}^{+}$cyanide in addition to 2-deoxyglucose, or by using diazoxide to open the channel without ATP depletion. These treatments induce a strong inward current that depolarizes the cell completely to 0 $\mathrm{mV}$ and induces cytotoxic edema and cell blebbing. These effects are reproduced without ATP depletion by diazoxide. ${ }^{26}$ After these treatments, cells die predominantly by oncosis, not by apoptosis. ${ }^{137}$

The effect of channel blocking using glibenclamide has been studied in vitro in reactive astrocytes that express the channel. ${ }^{25,137}$ In cells exposed to $\mathrm{Na}^{+}$azide to intentionally deplete ATP, glibenclamide blocks membrane depolariza- tion, significantly reduces blebbing associated with cytotoxic edema, and significantly reduces oncotic cell death.

The effect of channel blocking using glibenclamide has also been studied in vivo in two rat models of ischemic stroke. ${ }^{137}$ In a model of massive ischemic stroke with malignant cerebral edema associated with high mortality $(68 \%)$, glibenclamide reduced mortality and cerebral edema (excess water) by half. In a model of stroke induced by thromboemboli with delayed spontaneous reperfusion, glibenclamide reduced lesion volume by half, and its use is associated with cortical sparing attributed to improved leptomeningeal collateral blood flow due to reduced mass effect from edema.

\section{The TRP Channels}

The TRP channel superfamily derives its name from its role in Drosophila phototransduction. This family contains more than 50 members, 28 of which are known to be expressed in mammals. These channels vary in their modes of activation. Some TRP channels are constitutively open, and others react to diverse stimuli such as $\mathrm{pH}$, redox state, osmolarity, stretching, voltage, and intracellular $\mathrm{Ca}^{2+}{ }^{209,164}$ Some of these channels are selective for $\mathrm{Ca}^{2+}$, and others are nonselective and permeable to monovalent and/or divalent cations. The TRPs are subdivided into six subfamilies based on homology. The TRP proteins tend to form heteromultimers and can exhibit interdependent expression..$^{1,122}$

Analysis of promoter regions of TRPC and TRPM subfamily members TRPC1-7 and TRPM1-8 shows these members to possess multiple consensus binding sites for one or more of the transcription factors linked to ischemic stroke, suggesting possible involvement in hypoxic injury to CNS. ${ }^{139}$

Recent in vitro work unmasked a $\mathrm{Ca}^{2+}-$ mediated cell death mechanism associated with a $\mathrm{Ca}^{2+}$-permeable nonselective cation conductance carried by TRPM7 in cultures of mixed cortical neurons subjected to oxygen/glucose deprivation, followed by a return to normoxic conditions with an antiexcitotoxic combination. ${ }^{1}$ Suppressing TRPM7 expression blocked TRPM7 currents, which are known to be potentiated by acidosis, anoxic $\mathrm{Ca}^{2+}$ uptake, production of reactive oxygen species, and anoxic death. ${ }^{67}$ Most important, channel blocking eliminated the need for the antiexcitotoxic mixture and permitted the survival of neurons previously destined to die from prolonged anoxia. ${ }^{1}$ Both TRPM7 and TRPM2 are now believed to be important contributors to the paradoxical increase in intracellular $\mathrm{Ca}^{2+}$ levels that can lead to cell death following restoration of extracellular $\mathrm{Ca}^{2+}$ and/or postischemia. ${ }^{2,3,88,95,107}$ The subfamily member TRPM2 is abundantly expressed in the brain, where it functions as a cell death-mediating $\mathrm{Ca}^{2+}$-permeable cation channel. It possesses both ion channel and ADP-ribose hydrolase functions. Stress-related accumulation of cytosolic ADPribose released from mitochondria is required for gating of TRPM2 channels. ${ }^{120}$ Inhibition of TRPM2 function by poly-ADP-ribose-polymerase-1 inhibitors protects cells from oxidative stress-induced death. ${ }^{53,98,99}$

Studies of TRPC channels in vivo suggest that they serve as redox sensors ${ }^{49}$ in regulating endothelial barrier function, ${ }^{5}$ which is crucial in the formation of edema in 
ischemic stroke. ${ }^{138}$ The TRPC4 protein is also found to be significantly elevated in the rat striatum and hippocampus in rat models of MCA occlusion, in which immunoreactivity is localized to neuronal membranes. ${ }^{42}$ Numerous other TRP proteins have been shown to be localized in the mammalian vasculature. ${ }^{13,39,85,157,174}$

The TRPV1 subunit, widely expressed in the brain, has been suggested to be involved in neurodegenerative mechanisms occurring in ischemia and hypoxia. ${ }^{92,97}$ In a model of global cerebral ischemia in gerbils, both capsaicin ${ }^{118,119}$ and rimonabant ${ }^{20,55}$ exert neuroprotective effects that are at least partially attributable to TRPV1.

\section{The NKCC Channel}

The electroneutral cotransporter NKCC is encoded by a gene from the cation-chloride cotransporter family. This channel mediates the coupled movement of $\mathrm{Na}^{+}$and/or $\mathrm{K}^{+}$ with $\mathrm{Cl}^{-}$, with a stoichiometry of $1 \mathrm{Na}^{+}: 2 \mathrm{~K}^{+}: 2 \mathrm{Cl}^{-}$. Activity of this transporter is involved in regulatory ion responses of glia, neurons, endothelium, and choroid plexus epithelial cells. ${ }^{144,156,165,173}$ Although two isoforms are found, only NKCC1, the "housekeeping" isoform of the NKCC channel, plays a role in sodium secretion and absorption, cell volume regulation, and maintenance of intracellular $\mathrm{Cl}^{-}$ concentration in the CNS. ${ }^{32,50,130,169}$ Loop diuretics, such as bumetanide, can inhibit the channel..$^{38}$

The NKCC1 isoform is involved in secondary transport of inorganic ions. The driving force for ion flux originates in the $\mathrm{Na}^{+}$gradient created by $\mathrm{Na}^{+} / \mathrm{K}^{+}$-ATPase, with an important contribution of the $\mathrm{Cl}^{-}$gradient in epithelial cells. The NKCC cotransporter requires that all three ions $\left(\mathrm{Na}^{+}, \mathrm{K}^{+}\right.$, and $\left.\mathrm{Cl}^{-}\right)$be simultaneously present on the same side of the membrane. ${ }^{130} \mathrm{~A}$ decrease in intracellular $\mathrm{Cl}^{-}$, hypertonic stress, increased intracellular $\mathrm{Ca}^{2+}$, and $\beta$ adrenergic receptor stimulation ${ }^{31,34,81,135}$ result in phosphorylation of NKCC1, which increases channel activity. Kinases and phosphatases contribute to NKCC1 regulation through their opposing effects. .1,35,51,87,121 $^{2}$

The NKCC1 isoform plays an important role in maintaining physiological intracellular $\mathrm{Na}^{+}$concentration levels. However, in pathological situations, such as ischemia and hypoxia, it has been shown to contribute to excessive $\mathrm{Na}^{+}$inflow, which results in cytotoxic edema. In vitro data in neurons show that loss of $\mathrm{Cl}^{-}$is a sufficient and necessary stimulus for activation of NKCC $1 .{ }^{135}$ Similarly, work in astrocytes shows elevated levels of extracellular $\mathrm{K}^{+}$to be sufficient and necessary to activate astrocytic NKCC1. Genetic ablation of NKCC1, as well as its block by bumetanide, ${ }^{17}$ causes a decrease in intracellular $\mathrm{Cl}^{-}$in hypoxic neurons ${ }^{145}$ and blocks $\mathrm{Na}^{+}$- and $\mathrm{Cl}^{-}$-mediated cell swelling in astrocytes..$^{101,142,143}$

In vivo studies have shown that intracerebral bumetanide administered via a microdialysis probe, either prior to or during ischemia/hypoxia insult caused by temporary MCA occlusion, is neuroprotective, ameliorates brain damage, and reduces brain edema in rat focal ischemia, ${ }^{141,172,173}$ reinforcing the in vitro data. Focal cerebral ischemia in rats results in elevated $\mathrm{NKCC1}$ protein levels in the ipsilateral cortex and striatum. ${ }^{173}$ Together, these data show that NKCC1 merits further study to clarify its role in the early stages of ischemic cytotoxic damage.

\section{The NMDA Receptor Channel}

The ionotropic glutamate receptor channels are designated by three main classes, based on their preferential affinity to agonists. One class, the NMDA receptor channels, is unique because it is ligand-gated by a concurrent binding of glutamic acid and glycine and is voltage-dependent. At resting membrane potential, this receptor channel is blocked by an " $\mathrm{Mg}^{2+}$ plug," even if both the agonists are occupying their respective binding sites. Depolarization of the cell membrane removes this $\mathrm{Mg}^{2+}$ block and allows the channel to conduct $\mathrm{Na}^{+}, \mathrm{K}^{+}$, and $\mathrm{Ca}^{2+}{ }^{102,134}$ This duplex regulation is an integral mechanism in cellular control of $\mathrm{Ca}^{2+}$ homeostasis in neurons. The calcium ion participates in multiple molecular mechanisms involved in various cellular processes, but also causes cell death via activation of $\mathrm{Ca}^{2+}$-dependent proteases, formation of reactive oxygen species, phospholipase A2, and mitochondrial damage..$^{80}$

Glutamate is the principal neurotransmitter in the CNS. The NMDA receptor channels are found on most neurons, ${ }^{158,159}$ where they are involved in multiple crucial aspects of physiological and pathological brain activity. ${ }^{30}$ Under resting conditions, the glutamate concentration in the synaptic cleft consists of approximately $0.6 \mu \mathrm{M}^{23,29}$ During hypoxic or ischemic insult, values as high as $320 \mu \mathrm{M}$ are reached and sustained for a period of minutes to hours, ${ }^{149}$ resulting in cell depolarization, removal of the $\mathrm{Mg}^{2+}$ block, and an unregulated influx of $\mathrm{Na}^{+}$and $\mathrm{Ca}^{2+}$ into the cell, with consequent cell death by excitotoxicity. ${ }^{128,129}$ It is not solely the amount of released glutamate at the synapses, ${ }^{29}$ but also the duration of exposure to this excitatory neurotransmitter, that is believed to cause injury. ${ }^{160}$

Neuronal death in stroke, trauma, and other neurological disorders has been directly linked to the activation of NMDA receptor channels and consequent $\mathrm{Ca}^{2+}$-mediated excitotoxicity. ${ }^{57,104}$ It is generally agreed that acute excitotoxic neurodegeneration after glutamate receptor activation could be $\mathrm{Ca}^{2+}$-independent, but dependent on $\mathrm{Na}^{+}$and $\mathrm{Cl}^{-}$entry. ${ }^{28,127}$ Activation of NMDA receptors triggers a significant increase in intracellular $\mathrm{Na}^{+}$and $\mathrm{Cl}^{-}$content in cortical neurons. ${ }^{155}$ Blockage of $\mathrm{Na}^{+}$and $\mathrm{Cl}^{-}$entry by removal of extracellular $\mathrm{Na}^{+}$and $\mathrm{Cl}^{-}$abolishes NMDAmediated neurodegeneration. ${ }^{27,54}$

The NMDA receptor channel remains one of the most studied pertaining to CNS pathology. Several NMDA antagonists are currently undergoing clinical trials. Memantine, a channel blocker ${ }^{24}$ used as part of a combination therapy, has shown great promise in improving dementia symptoms. Other diseases, such as Parkinson and Huntington diseases, multiple sclerosis, amyotrophic lateral sclerosis, and epilepsy might benefit from treatment with NMDA antagonists. . $8,45,96,117,133$ To date, however, NMDA receptor strategies have not been successful at a clinical level in treating ischemia- or hypoxia-related injury, despite in vitro and in vivo data that strongly support this approach. ${ }^{123}$

\section{The AQP Channels}

Transport of water across biological membranes occurs passively. Water molecules can dissolve in lipid bilayers 
and move across cell membranes at a low but finite rate by simple diffusion. Yet because this process is inefficient, plasma membranes of many types of cells have developed specialized water channels (the AQPs) that serve as passive conduits for water transport, greatly increasing membrane water permeability.,76 The AQP channels are small transmembrane proteins, initially described in water transport in nephrons, that selectively transport water and in some cases glycerol, urea, and even hydrogen peroxide..$^{22}$ Thirteen different AQPs have been identified in mammals. Seven members of the AQP family have been described in the CNS to date.

The AQP1 type is found in the apical domain of the choroid plexus epithelial cells, in vasculature, ${ }^{58,140}$ dorsal root ganglia cell bodies, and in both the peripheral and central branches of primary afferent neurons. ${ }^{136}$ It may be involved in human brain tumor edema formation ${ }^{113}$ and nitric-oxide-dependent vasorelaxation, ${ }^{58}$ as well as in nociceptive processing. For three AQP channel typesAQP3, AQP5, and AQP8-mRNA is found in astrocytes, with levels altered by hypoxia. ${ }^{171}$ The AQP4 type, the most abundant and well-studied member of the AQP family found in the brain, is predominantly expressed in astrocytic foot processes surrounding blood vessels and ependymocytes facing capillaries and cerebrospinal fluid. ${ }^{40,109}$ It is implicated in the formation of brain edema. ${ }^{70,74,108,109}$ The proximity of the AQP4 channel to synapses of neurons allows for efficient clearance of $\mathrm{K}^{+}$ and water from synaptic junctions after excitation of neurons. ${ }^{103}$

Studies of AQP4-null mice demonstrated no obvious neurological abnormalities. These mice, however, show significantly lower levels of brain swelling after cellular edema produced by either acute water intoxication or ischemic stroke. ${ }^{91}$ Interestingly, transient MCA occlusion results in temporary loss of perivascular AQP4 in the neocortex,${ }^{41}$ possibly providing an explanation for the pathophysiology involved in salutary effects of hypoxic preconditioning. In pneumococcus-induced meningitis as well, brain edema, as well as mortality, were significantly reduced $^{116}$ in the absence of AQP4. None of the benefits reported in AQP4-knockout models with MCA occlusion, however, is observed in vasogenic edema, cortical freeze injury, and brain tumor models; in contrast, brain swelling, intracranial pressure, and general outcome are all worse than in controls. ${ }^{114,115}$ Also, AQP4 deficiency impairs astroglial cell migration in brain injury., ${ }^{9,132}$

Two different isoforms of AQP9 are localized to mitochondria in tanycyte and astrocyte cell bodie ${ }^{11,12}$ and midbrain dopaminergic neurons. ${ }^{7}$ It is believed that the flux of lactate and other metabolites through AQP9 enables mitochondria to adjust to extramitochondrial cytoplasm. The AQP11 isoform is found in the endoplasmic reticulum in Purkinje cells, hippocampal neurons of CA1 and CA2, and cerebral cortical neurons. ${ }^{48}$

Given the functional synergy between ion channels and AQPs, it is only logical to expect that attempts would be made to target $\mathrm{AQP}$ in the brain therapeutically using either agonists or antagonists. Several carbonic anhydrase inhibitors, ${ }^{63}$ as well as quaternary ammonium compounds, ${ }^{33}$ mercurial sulfhydryl compounds, lithium, silver, and gold, ${ }^{110}$ have been shown to inhibit AQPs, but these compounds are too nonspecific and/or toxic for in vivo use.

\section{Conclusions}

Excessive accumulation of brain water in cerebral edema is of central importance in neurosurgery. ${ }^{36,37}$ Brain edema leads to worsening of ischemia, and often to herniation and death. Despite large-scale multinational interest in neuroprotection, hyperosmolar agents and supportive surgical procedures such as cerebrospinal fluid diversion and surgical decompression remain the only current treatments for brain swelling. ${ }^{10,150,163}$

Advances in translational research now clearly identify cytotoxic edema as the initial, and most important, reversible first step in the sequence that leads to ionic edema, vasogenic edema, and complete hemorrhagic conversion. Cytotoxic edema is important in all brain cells, but is most conspicuous in astrocytes. A number of nonselective cation channel blockers show promising salutary effects in cerebral ischemia or ischemic stroke models, consistent with possible involvement of their targets, including ASIC, SUR1-regulated $\mathrm{NC}_{\mathrm{Ca}-\mathrm{ATP}}$ channels, and TRP channels in hypoxic insults. Although much work remains before appropriately targeted therapies can be implemented in the clinical setting, recent developments in molecular medicine hold great promise for new avenues in which CNS injury can be ameliorated.

\section{References}

1. Aarts M, Iihara K, Wei WL, Xiong ZG, Arundine M, Cerwinski $\mathrm{W}$, et al: A key role for TRPM7 channels in anoxic neuronal death. Cell 115:863-877, 2003

2. Aarts MM, Tymianski M: TRPM7 and ischemic CNS injury. Neuroscientist 11:116-123, 2005

3. Aarts MM, Tymianski M: TRPMs and neuronal cell death. Pflugers Arch 451:243-249, 2005

4. Agre P, Preston GM, Smith BL, Jung JS, Raina S, Moon C, et al: Aquaporin CHIP: the archetypal molecular water channel. Am J Physiol 265: F463-F476, 1993

5. Ahmmed GU, Malik AB: Functional role of TRPC channels in the regulation of endothelial permeability. Pflugers Arch 451: $131-142,2005$

6. Allen NJ, Attwell D: Modulation of ASIC channels in rat cerebellar Purkinje neurons by ischaemia-related signals. J Physiol 543:521-529, 2002

7. Amiry-Moghaddam M, Lindland H, Zelenin S, Roberg BA, Gundersen BB, Petersen P, et al: Brain mitochondria contain aquaporin water channels: evidence for the expression of a short AQP9 isoform in the inner mitochondrial membrane. FASEB J 19:1459-1467, 2005

8. Amiry-Moghaddam M, Ottersen OP: The molecular basis of water transport in the brain. Nat Rev Neurosci 4:991-1001, 2003

9. Auguste KI, Jin S, Uchida K, Yan D, Manley GT, Papadopoulos $\mathrm{MC}$, et al: Greatly impaired migration of implanted aquaporin-4-deficient astroglial cells in mouse brain toward a site of injury. FASEB J 21:108-116, 2007

10. Ayata C, Ropper AH: Ischaemic brain oedema. J Clin Neurosci 9:113-124, 2002

11. Badaut J, Hirt L, Granziera C, Bogousslavsky J, Magistretti PJ, Regli L: Astrocyte-specific expression of aquaporin-9 in mouse brain is increased after transient focal cerebral ischemia. J Cereb Blood Flow Metab 21:477-482, 2001

12. Badaut J, Lasbennes F, Magistretti PJ, Regli L: Aquaporins in 
brain: distribution, physiology, and pathophysiology. J Cereb Blood Flow Metab 22:367-378, 2002

13. Balzer M, Lintschinger B, Groschner K: Evidence for a role of Trp proteins in the oxidative stress-induced membrane conductances of porcine aortic endothelial cells. Cardiovasc Res 42: 543-549, 1999

14. Barros LF, Castro J, Bittner CX: Ion movements in cell death: from protection to execution. Biol Res 35:209-214, 2002

15. Barros LF, Hermosilla T, Castro J: Necrotic volume increase and the early physiology of necrosis. Comp Biochem Physiol A Mol Integr Physiol 130:401-409, 2001

16. Bassler EL, Ngo-Anh TJ, Geisler HS, Ruppersberg JP, Grunder S: Molecular and functional characterization of acid-sensing ion channel (ASIC) 1b. J Biol Chem 276:33782-33787, 2001

17. Beck J, Lenart B, Kintner DB, Sun D: Na-K-Cl cotransporter contributes to glutamate-mediated excitotoxicity. J Neurosci 23:5061-5068, 2003

18. Beister A, Kraus P, Kuhn W, Dose M, Weindl A, Gerlach M: The N-methyl-D-aspartate antagonist memantine retards progression of Huntington's disease. J Neural Transm Suppl 68: 117-122, 2004

19. Benveniste M, Dingledine R: Limiting stroke-induced damage by targeting an acid channel. N Engl J Med 352:85-86, 2005

20. Berger C, Schmid PC, Schabitz WR, Wolf M, Schwab S, Schmid HH: Massive accumulation of $\mathrm{N}$-acylethanolamines after stroke. Cell signalling in acute cerebral ischemia? J Neurochem 88:1159-1167, 2004

21. Betz AL, Iannotti F, Hoff JT: Brain edema: a classification based on blood-brain barrier integrity. Cerebrovasc Brain Metab Rev 1:133-154, 1989

22. Bienert GP, Moller AL, Kristiansen KA, Schulz A, Moller IM, Schjoerring JK, et al: Specific aquaporins facilitate the diffusion of hydrogen peroxide across membranes. J Biol Chem 282: 1183-1192, 2007

23. Bouvier M, Szatkowski M, Amato A, Attwell D: The glial cell glutamate uptake carrier countertransports $\mathrm{pH}$-changing anions. Nature 360:471-474, 1992

24. Chen HS, Pellegrini JW, Aggarwal SK, Lei SZ, Warach S, Jensen FE, et al: Open-channel block of N-methyl-D-aspartate (NMDA) responses by memantine: therapeutic advantage against NMDA receptor-mediated neurotoxicity. J Neurosci 12:4427-4436, 1992

25. Chen M, Dong Y, Simard JM: Functional coupling between sulfonylurea receptor type 1 and a nonselective cation channel in reactive astrocytes from adult rat brain. J Neurosci 23: 8568-8577, 2003

26. Chen M, Simard JM: Cell swelling and a nonselective cation channel regulated by internal $\mathrm{Ca}^{2+}$ and ATP in native reactive astrocytes from adult rat brain. J Neurosci 21:6512-6521, 2001

27. Chen Q, Olney JW, Lukasiewicz PD, Almli T, Romano C: $\mathrm{Ca}^{2+}$ independent excitotoxic neurodegeneration in isolated retina, an intact neural net: a role for $\mathrm{Cl}^{-}$and inhibitory transmitters. Mol Pharmacol 53:564-572, 1998

28. Choi DW, Maulucci-Gedde M, Kriegstein AR: Glutamate neurotoxicity in cortical cell culture. J Neurosci 7:357-368, 1987

29. Clements JD, Lester RA, Tong G, Jahr CE, Westbrook GL: The time course of glutamate in the synaptic cleft. Science 258: 1498-1501, 1992

30. Danbolt NC: Glutamate uptake. Prog Neurobiol 65:1-105, 2001

31. Darman RB, Forbush B: A regulatory locus of phosphorylation in the $\mathrm{N}$ terminus of the $\mathrm{Na}-\mathrm{K}-\mathrm{Cl}$ cotransporter, NKCC1. J Biol Chem 277:37542-37550, 2002

32. Delpire E, Mount DB: Human and murine phenotypes associated with defects in cation-chloride cotransport. Annu Rev Physiol 64:803-843, 2002

33. Detmers FJ, de Groot BL, Muller EM, Hinton A, Konings IB, Sze M, et al: Quaternary ammonium compounds as water chan- nel blockers. Specificity, potency, and site of action. J Biol Chem 281:14207-14214, 2006

34. Di Ciano-Oliveira C, Sirokmany G, Szaszi K, Arthur WT, Masszi A, Peterson M, et al: Hyperosmotic stress activates Rho: differential involvement in Rho kinase-dependent MLC phosphorylation and NKCC activation. Am J Physiol Cell Physiol 285:C555-C566, 2003

35. Dowd BF, Forbush B: PASK (proline-alanine-rich STE20-related kinase), a regulatory kinase of the $\mathrm{Na}-\mathrm{K}-\mathrm{Cl}$ cotransporter (NKCC1). J Biol Chem 278:27347-27353, 2003

36. Fishman RA: Brain edema. N Engl J Med 293:706-711, 1975

37. Fishman RA: Brain edema: mechanisms and management. Rinsho Shinkeigaku 26:1268-1274, 1986

38. Forbush B III, Palfrey HC: [3H]bumetanide binding to membranes isolated from dog kidney outer medulla. Relationship to the $\mathrm{Na}, \mathrm{K}, \mathrm{Cl}$ co-transport system. J Biol Chem 258: 11787-11792, 1983

39. Freichel M, Philipp S, Cavalie A, Flockerzi V: TRPC4 and TRPC4-deficient mice. Novartis Found Symp 258:189-199, 2004

40. Frigeri A, Gropper MA, Turck CW, Verkman AS: Immunolocalization of the mercurial-insensitive water channel and glycerol intrinsic protein in epithelial cell plasma membranes. Proc Natl Acad Sci U S A 92:4328-4331, 1995

41. Frydenlund DS, Bhardwaj A, Otsuka T, Mylonakou MN, Yasumura T, Davidson KG, et al: Temporary loss of perivascular aquaporin-4 in neocortex after transient middle cerebral artery occlusion in mice. Proc Natl Acad Sci U S A 103: 13532-13536, 2006

42. Gao YQ, Gao H, Zhou ZY, Lu SD, Sun FY: [Expression of transient receptor potential channel 4 in striatum and hippocampus of rats is increased after focal cerebral ischemia.] Sheng Li Xue Bao 56:153-157, 2004 (Chinese)

43. Garcia JH, Liu KF, Yoshida Y, Chen S, Lian J: Brain microvessels: factors altering their patency after the occlusion of a middle cerebral artery (Wistar rat). Am J Pathol 145:728-740, 1994

44. Garcia JH, Yoshida Y, Chen H, Li Y, Zhang ZG, Lian J, et al: Progression from ischemic injury to infarct following middle cerebral artery occlusion in the rat. Am J Pathol 142:623-635, 1993

45. Geter-Douglass B, Witkin JM: Behavioral effects and anticonvulsant efficacies of low-affinity, uncompetitive NMDA antagonists in mice. Psychopharmacology 146:280-289, 1999

46. Go KG: The normal and pathological physiology of brain water. Adv Tech Stand Neurosurg 23:47-142, 1997

47. Goldstein LB, Adams R, Alberts MJ, Appel LJ, Brass LM, Bushnell CD, et al: Primary prevention of ischemic stroke: a guideline from the American Heart Association/American Stroke Association Stroke Council: cosponsored by the Atherosclerotic Peripheral Vascular Disease Interdisciplinary Working Group; Cardiovascular Nursing Council; Clinical Cardiology Council; Nutrition, Physical Activity, and Metabolism Council; and the Quality of Care and Outcomes Research Interdisciplinary Working Group. Circulation 113:E873-E923, 2006

48. Gorelick DA, Praetorius J, Tsunenari T, Nielsen S, Agre P: Aquaporin-11: a channel protein lacking apparent transport function expressed in brain. BMC Biochem 7:14, 2006

49. Groschner K, Rosker C, Lukas M: Role of TRP channels in oxidative stress. Novartis Found Symp 258:222-235, 2004

50. Haas M, Forbush B III: The Na-K-Cl cotransporter of secretory epithelia. Annu Rev Physiol 62:515-534, 2000

51. Haas M, McBrayer D, Lytle C: $\left[\mathrm{Cl}^{-}\right] \mathrm{i}$-dependent phosphorylation of the Na-K-Cl cotransport protein of dog tracheal epithelial cells. J Biol Chem 270:28955-28961, 1995

52. Hackett PH, Yarnell PR, Hill R, Reynard K, Heit J, McCormick J: High-altitude cerebral edema evaluated with magnetic resonance imaging: clinical correlation and pathophysiology. JAMA 280:1920-1925, 1998 
53. Hara Y, Wakamori M, Ishii M, Maeno E, Nishida M, Yoshida T, et al: LTRPC2 $\mathrm{Ca}^{2+}$-permeable channel activated by changes in redox status confers susceptibility to cell death. Mol Cell 9:163-173, 2002

54. Hasbani MJ, Hyrc KL, Faddis BT, Romano C, Goldberg MP: Distinct roles for sodium, chloride, and calcium in excitotoxic dendritic injury and recovery. Exp Neurol 154:241-258, 1998

55. Henness S, Robinson DM, Lyseng-Williamson KA: Rimonabant. Drugs 66:2109-2121, 2006

56. Heo JH, Han SW, Lee SK: Free radicals as triggers of brain edema formation after stroke. Free Radic Biol Med 39:51-70, 2005

57. Herlenius E, Lagercrantz H: Development of neurotransmitter systems during critical periods. Exp Neurol 190 Suppl 1: S8-S21, 2004

58. Herrera M, Garvin JL: Novel role of AQP-1 in NO-dependent vasorelaxation. Am J Physiol Renal Physiol: Jan, 2007 [Epub ahead of print]

59. Hoehn-Berlage M, Hossmann KA, Busch E, Eis M, Schmitz B, Gyngell ML: Inhibition of nonselective cation channels reduces focal ischemic injury of rat brain. J Cereb Blood Flow Metab 17:534-542, 1997

60. Hossmann KA: Glutamate-mediated injury in focal cerebral ischemia: the excitotoxin hypothesis revised. Brain Pathol 4: 23-36, 1994

61. Hossmann KA: Viability thresholds and the penumbra of focal ischemia. Ann Neurol 36:557-565, 1994

62. Hossmann KA, Fischer M, Bockhorst K, Hoehn-Berlage M: NMR imaging of the apparent diffusion coefficient (ADC) for the evaluation of metabolic suppression and recovery after prolonged cerebral ischemia. J Cereb Blood Flow Metab 14: 723-731, 1994

63. Huber VJ, Tsujita M, Yamazaki M, Sakimura K, Nakada T: Identification of arylsulfonamides as Aquaporin 4 inhibitors. Bioorg Med Chem Lett 17:1270-1273, 2006

64. Immke DC, McCleskey EW: Lactate enhances the acid-sensing $\mathrm{Na}^{+}$channel on ischemia-sensing neurons. Nat Neurosci 4: 869-870, 2001

65. Immke DC, McCleskey EW: Protons open acid-sensing ion channels by catalyzing relief of $\mathrm{Ca}^{2+}$ blockade. Neuron 37: 75-84, 2003

66. Jacewicz M, Kiessling M, Pulsinelli WA: Selective gene expression in focal cerebral ischemia. J Cereb Blood Flow Metab 6:263-272, 1986

67. Jiang J, Li M, Yue L: Potentiation of TRPM7 inward currents by protons. J Gen Physiol 126:137-150, 2005

68. Johnson MB, Jin K, Minami M, Chen D, Simon RP: Global ischemia induces expression of acid-sensing ion channel 2a in rat brain. J Cereb Blood Flow Metab 21:734-740, 2001

69. Jones TH, Morawetz RB, Crowell RM, Marcoux FW, FitzGibbon SJ, DeGirolami U, et al: Thresholds of focal cerebral ischemia in awake monkeys. J Neurosurg 54:773-782, 1981

70. Jung JS, Bhat RV, Preston GM, Guggino WB, Baraban JM, Agre P: Molecular characterization of an aquaporin cDNA from brain: candidate osmoreceptor and regulator of water balance. Proc Natl Acad Sci U S A 91:13052-13056, 1994

71. Kempski O: Cerebral edema. Semin Nephrol 21:303-307, 2001

72. Kimelberg HK: Current concepts of brain edema. Review of laboratory investigations. J Neurosurg 83:1051-1059, 1995

73. Kimelberg HK: Water homeostasis in the brain: basic concepts. Neuroscience 129:851-860, 2004

74. King LS, Agre P: Pathophysiology of the aquaporin water channels. Annu Rev Physiol 58:619-648, 1996

75. Klatzo I: Presidental address. Neuropathological aspects of brain edema. J Neuropathol Exp Neurol 26:1-14, 1967

76. Knepper MA: The aquaporin family of molecular water channels. Proc Natl Acad Sci U S A 91:6255-6258, 1994
77. Krishtal OA, Pidoplichko VI: Receptor for protons in the membrane of sensory neurons. Brain Res 214:150-154, 1981

78. Krishtal OA, Pidoplichko VI: A "receptor" for protons in small neurons of trigeminal ganglia: possible role in nociception. Neurosci Lett 24:243-246, 1981

79. Krishtal OA, Pidoplichko VI: A receptor for protons in the nerve cell membrane. Neuroscience 5:2325-2327, 1980

80. Kristian T, Siesjo BK: Calcium in ischemic cell death. Stroke 29:705-718, 1998

81. Kurihara K, Moore-Hoon ML, Saitoh M, Turner RJ: Characterization of a phosphorylation event resulting in upregulation of the salivary $\mathrm{Na}(+)-\mathrm{K}(+)-2 \mathrm{Cl}(-)$ cotransporter. Am J Physiol 277:C1184-C1193, 1999

82. Langlois JA, Rutland-Brown W, Thomas KE: The incidence of traumatic brain injury among children in the United States: differences by race. J Head Trauma Rehabil 20:229-238, 2005

83. Langlois JA, Rutland-Brown W, Wald MM: The epidemiology and impact of traumatic brain injury: a brief overview. J Head Trauma Rehabil 21:375-378, 2006

84. Lee JM, Grabb MC, Zipfel GJ, Choi DW: Brain tissue responses to ischemia. J Clin Invest 106:723-731, 2000

85. Lin MJ, Leung GP, Zhang WM, Yang XR, Yip KP, Tse CM, et $\mathrm{al}$ : Chronic hypoxia-induced upregulation of store-operated and receptor-operated $\mathrm{Ca}^{2+}$ channels in pulmonary arterial smooth muscle cells: a novel mechanism of hypoxic pulmonary hypertension. Circ Res 95:496-505, 2004

86. Lundbaek JA, Hansen AJ: Brain interstitial volume fraction and tortuosity in anoxia. Evaluation of the ion-selective micro-electrode method. Acta Physiol Scand 146:473-484, 1992

87. Lytle C, Forbush B III: Regulatory phosphorylation of the secretory $\mathrm{Na}-\mathrm{K}-\mathrm{Cl}$ cotransporter: modulation by cytoplasmic $\mathrm{Cl}$. Am J Physiol 270:C437-C448, 1996

88. MacDonald JF, Xiong ZG, Jackson MF: Paradox of $\mathrm{Ca}^{2+}$ signaling, cell death and stroke. Trends Neurosci 29:75-81, 2006

89. Majno G, Joris I: Apoptosis, oncosis, and necrosis. An overview of cell death. Am J Pathol 146:3-15, 1995

90. Manley GT, Binder DK, Papadopoulos MC, Verkman AS: New insights into water transport and edema in the central nervous system from phenotype analysis of aquaporin-4 null mice. Neuroscience 129:983-991, 2004

91. Manley GT, Fujimura M, Ma T, Noshita N, Filiz F, Bollen AW, et al: Aquaporin-4 deletion in mice reduces brain edema after acute water intoxication and ischemic stroke. Nat Med 6: $159-163,2000$

92. Marinelli S, Vaughan CW, Christie MJ, Connor M: Capsaicin activation of glutamatergic synaptic transmission in the rat locus coeruleus in vitro. J Physiol 543:531-540, 2002

93. Marmarou A, Signoretti S, Aygok G, Fatouros P, Portella G: Traumatic brain edema in diffuse and focal injury: cellular or vasogenic? Acta Neurochir Suppl 96:24-29, 2006

94. Marmarou A, Signoretti S, Fatouros PP, Portella G, Aygok GA, Bullock MR: Predominance of cellular edema in traumatic brain swelling in patients with severe head injuries. J Neurosurg 104:720-730, 2006

95. McNulty S, Fonfria E: The role of TRPM channels in cell death Pflugers Arch 451:235-242, 2005

96. Merello M, Nouzeilles MI, Cammarota A, Leiguarda R: Effect of memantine (NMDA antagonist) on Parkinson's disease: a double-blind crossover randomized study. Clin Neuropharmacol 22:273-276, 1999

97. Mezey E, Toth ZE, Cortright DN, Arzubi MK, Krause JE, Elde $\mathrm{R}$, et al: Distribution of mRNA for vanilloid receptor subtype 1 (VR1), and VR1-like immunoreactivity, in the central nervous system of the rat and human. Proc Natl Acad Sci U S A 97: 3655-3660, 2000

98. Miller BA: Inhibition of TRPM2 function by PARP inhibitors protects cells from oxidative stress-induced death. $\mathbf{B r} \mathbf{J}$ Pharmacol 143:515-516, 2004 
99. Miller BA: The role of TRP channels in oxidative stressinduced cell death. J Membr Biol 209:31-41, 2006

100. Mongin AA, Aksentsev SL, Orlov SN, Kvacheva ZB, Mezen NI, Fedulov AS, et al: Swelling-induced activation of $\mathrm{Na}^{+}, \mathrm{K}^{+}$, $2 \mathrm{Cl}^{-}$cotransport in $\mathrm{C} 6$ glioma cells: kinetic properties and intracellular signalling mechanisms. Biochim Biophys Acta 1285:229-236, 1996

101. Mongin AA, Kimelberg HK: ATP potently modulates anion channel-mediated excitatory amino acid release from cultured astrocytes. Am J Physiol Cell Physiol 283: C569-C578, 2002

102. Mori H, Mishina M: Structure and function of the NMDA receptor channel. Neuropharmacology 34:1219-1237, 1995

103. Nagelhus EA, Horio Y, Inanobe A, Fujita A, Haug FM, Nielsen $\mathrm{S}$, et al: Immunogold evidence suggests that coupling of $\mathrm{K}^{+}$ siphoning and water transport in rat retinal Muller cells is mediated by a coenrichment of Kir4.1 and AQP4 in specific membrane domains. Glia 26:47-54, 1999

104. Nakazawa K, McHugh TJ, Wilson MA, Tonegawa S: NMDA receptors, place cells and hippocampal spatial memory. Nat Rev Neurosci 5:361-372, 2004

105. Naves LA, McCleskey EW: An acid-sensing ion channel that detects ischemic pain. Braz J Med Biol Res 38:1561-1569, 2005

106. Nedergaard M, Kraig RP, Tanabe J, Pulsinelli WA: Dynamics of interstitial and intracellular $\mathrm{pH}$ in evolving brain infarct. Am J Physiol 260:R581-R588, 1991

107. Nicotera P, Bano D: The enemy at the gates. $\mathrm{Ca}^{2+}$ entry through TRPM7 channels and anoxic neuronal death. Cell 115: 768-770, 2003

108. Nielsen S, King LS, Christensen BM, Agre P: Aquaporins in complex tissues. II. Subcellular distribution in respiratory and glandular tissues of rat. Am J Physiol 273:C1549-C1561, 1997

109. Nielsen S, Nagelhus EA, Amiry-Moghaddam M, Bourque C, Agre P, Ottersen OP: Specialized membrane domains for water transport in glial cells: high-resolution immunogold cytochemistry of aquaporin-4 in rat brain. J Neurosci 17: 171-180, 1997

110. Niemietz CM, Tyerman SD: New potent inhibitors of aquaporins: silver and gold compounds inhibit aquaporins of plant and human origin. FEBS Lett 531:443-447, 2002

111. Okada Y, Maeno E: Apoptosis, cell volume regulation and volume-regulatory chloride channels. Comp Biochem Physiol A Mol Integr Physiol 130:377-383, 2001

112. Ostrowski RP, Colohan AR, Zhang JH: Molecular mechanisms of early brain injury after subarachnoid hemorrhage. Neurol Res 28:399-414, 2006

113. Papadopoulos M, Saadoun S, Krishna S, Bell B, Davies D: The aquaporin-1 water channel protein is abnormally expressed in oedematous human brain tumors. J Anat 200:531-532, 2002

114. Papadopoulos MC, Manley GT, Krishna S, Verkman AS: Aquaporin-4 facilitates reabsorption of excess fluid in vasogenic brain edema. FASEB J 18: 1291-1293, 2004

115. Papadopoulos MC, Saadoun S, Binder DK, Manley GT, Krishna S, Verkman AS: Molecular mechanisms of brain tumor edema. Neuroscience 129:1011-1020, 2004

116. Papadopoulos MC, Verkman AS: Aquaporin-4 gene disruption in mice reduces brain swelling and mortality in pneumococcal meningitis. J Biol Chem 280: 13906-13912, 2005

117. Paul C, Bolton C: Modulation of blood-brain barrier dysfunction and neurological deficits during acute experimental allergic encephalomyelitis by the N-methyl-D-aspartate receptor antagonist memantine. J Pharmacol Exp Ther 302:50-57, 2002

118. Pegorini S, Braida D, Verzoni C, Guerini-Rocco C, Consalez GG, Croci L, et al: Capsaicin exhibits neuroprotective effects in a model of transient global cerebral ischemia in Mongolian gerbils. Br J Pharmacol 144:727-735, 2005

119. Pegorini S, Zani A, Braida D, Guerini-Rocco C, Sala M:
Vanilloid VR1 receptor is involved in rimonabant-induced neuroprotection. Br J Pharmacol 147:552-559, 2006

120. Perraud AL, Takanishi CL, Shen B, Kang S, Smith MK, Schmitz C, et al: Accumulation of free ADP-ribose from mitochondria mediates oxidative stress-induced gating of TRPM2 cation channels. J Biol Chem 280:6138-6148, 2005

121. Piechotta K, Lu J, Delpire E: Cation chloride cotransporters interact with the stress-related kinases Ste20-related prolinealanine-rich kinase (SPAK) and oxidative stress response 1 (OSR1). J Biol Chem 277:50812-50819, 2002

122. Poteser M, Graziani A, Rosker C, Eder P, Derler I, Kahr H, et al: TRPC3 and TRPC4 associate to form a redox-sensitive cation channel. Evidence for expression of native TRPC3TRPC4 heteromeric channels in endothelial cells. J Biol Chem 281:13588-13595, 2006

123. Rao VL, Dogan A, Todd KG, Bowen KK, Dempsey RJ: Neuroprotection by memantine, a non-competitive NMDA receptor antagonist after traumatic brain injury in rats. Brain Res 911:96-100, 2001

124. Rehncrona S: Brain acidosis. Ann Emerg Med 14:770-776, 1985

125. Rhoney DH, Parker D Jr: Considerations in fluids and electrolytes after traumatic brain injury. Nutr Clin Pract 21: 462-478, 2006

126. Rosamond W, Flegal K, Friday G, Furie K, Go A, Greenlund K, et al: Heart Disease and Stroke Statistics-2007 update: a report from the American Heart Association Statistics Committee and Stroke Statistics Subcommittee. Circulation 115:E69-E179, 2007

127. Rothman SM: The neurotoxicity of excitatory amino acids is produced by passive chloride influx. J Neurosci 5: 1483-1489, 1985

128. Rothman SM, Olney JW: Excitotoxicity and the NMDA receptor-still lethal after eight years. Trends Neurosci 18:57-58, 1995

129. Rothman SM, Olney JW: Glutamate and the pathophysiology of hypoxic-ischemic brain damage. Ann Neurol 19:105-111, 1986

130. Russell JM: Sodium-potassium-chloride cotransport. Physiol $\operatorname{Rev}$ 80:211-276, 2000

131. Rutland-Brown W, Langlois JA, Thomas KE, Xi YL: Incidence of traumatic brain injury in the United States, 2003. J Head Trauma Rehabil 21:544-548, 2006

132. Saadoun S, Papadopoulos MC, Watanabe H, Yan D, Manley GT, Verkman AS: Involvement of aquaporin-4 in astroglial cell migration and glial scar formation. J Cell Sci 118: 5691-5698, 2005

133. Sang CN, Booher S, Gilron I, Parada S, Max MB: Dextromethorphan and memantine in painful diabetic neuropathy and postherpetic neuralgia: efficacy and doseresponse trials. Anesthesiology 96:1053-1061, 2002

134. Scatton B: The NMDA receptor complex. Fundam Clin Pharmacol 7:389-400, 1993

135. Schomberg SL, Su G, Haworth RA, Sun D: Stimulation of Na$\mathrm{K}-2 \mathrm{Cl}$ cotransporter in neurons by activation of non-NMDA ionotropic receptor and group-I mGluRs. J Neurophysiol 85:2563-2575, 2001

136. Shields SD, Mazario J, Skinner K, Basbaum AI: Anatomical and functional analysis of aquaporin 1 , a water channel in primary afferent neurons. Pain, 2007 [Epub ahead of print]

137. Simard JM, Chen M, Tarasov KV, Bhatta S, Ivanova S, Melnitchenko L, et al: Newly expressed SUR1-regulated NC(CaATP) channel mediates cerebral edema after ischemic stroke. Nat Med 12:433-440, 2006

138. Simard JM, Kent TA, Chen M, Tarasov KV, Gerzanich V: Brain oedema in focal ischemia: molecular pathophysiology and theoretical implications. Lancet Neurol 6:258-268, 2007

139. Simard JM, Tarasov KV, Gerzanich V: Non-selective cation 
channels, transient receptor potential channels and ischemic stroke. Biochim Biophys Acta, in press, 2007

140. Speake T, Freeman LJ, Brown PD: Expression of aquaporin 1 and aquaporin 4 water channels in rat choroid plexus. Biochim Biophys Acta 1609:80-86, 2003

141. Staub F, Stoffel M, Berger S, Eriskat J, Baethmann A: Treatment of vasogenic brain edema with the novel $\mathrm{Cl}^{-}$transport inhibitor torasemide. J Neurotrauma 11:679-690, 1994

142. Su G, Kintner DB, Flagella M, Shull GE, Sun D: Astrocytes from $\mathrm{Na}(+)-\mathrm{K}(+)-\mathrm{Cl}(-)$ cotransporter-null mice exhibit absence of swelling and decrease in EAA release. Am J Physiol Cell Physiol 282:C1147-C1160, 2002

143. Su G, Kintner DB, Sun D: Contribution of $\mathrm{Na}(+)-\mathrm{K}(+)-\mathrm{Cl}(-)$ cotransporter to high- $[\mathrm{K}(+)](0)$-induced swelling and EAA release in astrocytes. Am J Physiol Cell Physiol 282: C1136-C1146, 2002

144. Sun D, Lytle C, O'Donnell ME: Astroglial cell-induced expression of Na-K-Cl cotransporter in brain microvascular endothelial cells. Am J Physiol 269:C1506-C1512, 1995

145. Sung KW, Kirby M, McDonald MP, Lovinger DM, Delpire E: Abnormal GABAA receptor-mediated currents in dorsal root ganglion neurons isolated from $\mathrm{Na}-\mathrm{K}-2 \mathrm{Cl}$ cotransporter null mice. J Neurosci 20:7531-7538, 2000

146. Sweeney MI, Yager JY, Walz W, Juurlink BH: Cellular mechanisms involved in brain ischemia. Can J Physiol Pharmacol 73:1525-1535, 1995

147. Sykova E, Svoboda J, Polak J, Chvatal A: Extracellular volume fraction and diffusion characteristics during progressive ischemia and terminal anoxia in the spinal cord of the rat. J Cereb Blood Flow Metab 14:301-311, 1994

148. Szabo C: Mechanisms of cell necrosis. Crit Care Med 33 (12 Suppl):S530-S534, 2005

149. Szatkowski M, Attwell D: Triggering and execution of neuronal death in brain ischaemia: two phases of glutamate release by different mechanisms. Trends Neurosci 17: 359-365, 1994

150. Taylor CB, Haas GM, Maloney JE: Acute closed cerebral lesions treated by injection of hypertonic dextrose solution and by surgical decompression; a quantitative study. AMA Arch Pathol 48:525-535, 1949

151. Thurman DJ, Alverson C, Dunn KA, Guerrero J, Sniezek JE: Traumatic brain injury in the United States: A public health perspective. J Head Trauma Rehabil 14:602-615, 1999

152. Ugawa S, Ueda T, Ishida Y, Nishigaki M, Shibata Y, Shimada S: Amiloride-blockable acid-sensing ion channels are leading acid sensors expressed in human nociceptors. J Clin Invest 110: $1185-1190,2002$

153. Waldmann R, Champigny G, Lingueglia E, De Weille Jr, Heurteaux C, Lazdunski M: H(+)-gated cation channels. Ann N Y Acad Sci 868:67-76, 1999

154. Waldmann R, Lazdunski M: H(+)-gated cation channels: neuronal acid sensors in the NaC/DEG family of ion channels. Curr Opin Neurobiol 8:418-424, 1998

155. Walz W: Role of $\mathrm{Na} / \mathrm{K} / \mathrm{Cl}$ cotransport in astrocytes. Can $\mathbf{J}$ Physiol Pharmacol 70 Suppl:S260-S262, 1992

156. Wang H, Yan Y, Kintner DB, Lytle C, Sun D: GABA-mediated trophic effect on oligodendrocytes requires $\mathrm{Na}-\mathrm{K}-2 \mathrm{Cl}$ cotransport activity. J Neurophysiol 90:1257-1265, 2003

157. Wang J, Weigand L, Lu W, Sylvester JT, Semenza GL, Shimoda LA: Hypoxia inducible factor 1 mediates hypoxiainduced TRPC expression and elevated intracellular $\mathrm{Ca}^{2+}$ in pulmonary arterial smooth muscle cells. Circ Res 98: 1528-1537, 2006

158. Watanabe M, Inoue Y, Sakimura K, Mishina M: Developmental changes in distribution of NMDA receptor channel subunit mRNAs. Neuroreport 3:1138-1140, 1992

159. Watanabe M, Inoue Y, Sakimura K, Mishina M: Distinct spatio-temporal distributions of the NMDA receptor channel sub- unit mRNAs in the brain. Ann N Y Acad Sci 707:463-466, 1993

160. Waxman EA, Lynch DR: N-methyl-D-aspartate receptor subtypes: multiple roles in excitotoxicity and neurological disease. Neuroscientist 11:37-49, 2005

161. Wemmie JA, Chen J, Askwith CC, Hruska-Hageman AM, Price MP, Nolan BC, et al: The acid-activated ion channel ASIC contributes to synaptic plasticity, learning, and memory. Neuron 34:463-477, 2002

162. White BC, Sullivan JM, DeGracia DJ, O’Neil BJ, Neumar RW, Grossman LI, et al: Brain ischemia and reperfusion: molecular mechanisms of neuronal injury. J Neurol Sci 179:1-33, 2000

163. Wilkins RH, Weed LH, McKibben PS: Neurosurgical classic-XXXII. J Neurosurg 22:404-419, 1965

164. Woodard GE, Sage SO, Rosado JA: Transient receptor potential channels and intracellular signaling. Int Rev Cytol 256: 35-67, 2007

165. Wu Q, Delpire E, Hebert SC, Strange K: Functional demonstration of $\mathrm{Na}^{+}-\mathrm{K}^{+}-2 \mathrm{Cl}^{-}$cotransporter activity in isolated, polarized choroid plexus cells. Am J Physiol 275: C1565-C1572, 1998

166. Xi G, Keep RF, Hoff JT: Pathophysiology of brain edema formation. Neurosurg Clin N Am 13:371-383, 2002

167. Xiong ZG, Chu XP, Simon RP: $\mathrm{Ca}^{2+}$-permeable acid-sensing ion channels and ischemic brain injury. J Membr Biol 209: 59-68, 2006

168. Xiong ZG, Zhu XM, Chu XP, Minami M, Hey J, Wei WL, et al: Neuroprotection in ischemia: blocking calcium-permeable acid-sensing ion channels. Cell 118:687-698, 2004

169. Xu JC, Lytle C, Zhu TT, Payne JA, Benz E Jr, Forbush B III: Molecular cloning and functional expression of the bumetanide-sensitive Na-K-Cl cotransporter. Proc Natl Acad Sci U S A 91:2201-2205, 1994

170. Yagi J, Wenk HN, Naves LA, McCleskey EW: Sustained currents through ASIC3 ion channels at the modest $\mathrm{pH}$ changes that occur during myocardial ischemia. Circ Res 99:501-509, 2006

171. Yamamoto N, Yoneda K, Asai K, Sobue K, Tada T, Fujita Y, et al: Alterations in the expression of the AQP family in cultured rat astrocytes during hypoxia and reoxygenation. Brain Res Mol Brain Res 90:26-38, 2001

172. Yan Y, Dempsey RJ, Flemmer A, Forbush B, Sun D: Inhibition of $\mathrm{Na}(+)-\mathrm{K}(+)-\mathrm{Cl}(-)$ cotransporter during focal cerebral ischemia decreases edema and neuronal damage. Brain Res 961:22-31, 2003

173. Yan Y, Dempsey RJ, Sun D: $\mathrm{Na}^{+}-\mathrm{K}^{+}-\mathrm{Cl}^{-}$cotransporter in rat focal cerebral ischemia. J Cereb Blood Flow Metab 21: 711-721, 2001

174. Yao X, Garland CJ: Recent developments in vascular endothelial cell transient receptor potential channels. Circ Res 97: 853-863, 2005

Manuscript submitted February 15, 2007.

Accepted April 5, 2007.

This work was supported by grants to J.M.S. from the National Heart, Lung and Blood Institute (Grant Nos. HL051932 and HL082517), the National Institute of Neurological Disorders and Stroke (Grant No. NS048260), the US Department of Veterans Affairs (Baltimore VA, Baltimore, Maryland), and the Christopher Reeves Paralysis Foundation; and to V.G. from the National Institute on Drug Abuse (Grant No. DA018329) and the American Heart Association (Grant No. 0455634U).

Address reprint requests to: J. Marc Simard, M.D., Ph.D., University of Maryland Department of Neurological Surgery, 22 South Greene Street, Suite 12SD, Baltimore, Maryland 21201-1595. email: msimard@smail.umaryland.edu. 